\title{
Vermicompost soil amendment influences yield, growth responses and nutritional value of Kale (Brassica oleracea Acephala group), Radish (Raphanus sativus) and Tomato (Solanum lycopersicum L)
}

\author{
Elsa Calderon ${ }^{1}$ and Desmond G. Mortley ${ }^{2^{\star}}$ \\ ${ }^{1}$ Department of Environmental Sciences, Division of Physical and Biological Sciences, University of California, Santa \\ Cruz, California, USA. \\ ${ }^{2}$ College of Agriculture, Environment and Nutrition Sciences and G. W. Carver Agricultural Experiment Station, \\ Tuskegee University, Tuskegee, AL 36088, Alabama, USA.
}

Received 11 February, 2021; Accepted 6 April, 2021

\begin{abstract}
Greenhouse experiments were conducted to investigate the effects of various vermicompost amendments on growth responses and nutrient content of kale (Brassica oleracea Acephala group), radish (Raphanus sativus), and tomato (Solanum lycopersicum $\mathrm{L}$ ), using a completely randomized design with three crop species, four vermicompost treatments and four replications. The twelve treatment combinations consisted of vermicompost levels of $0,5,10$, and $15 \%(\mathrm{v} / \mathrm{v})$ and three crop species, kale, radish and tomato. Plants were grown in pots containing soil in which the respective vermicompost levels were incorporated. Three seeds of each species were sown in each pot and seedlings were thinned to one per pot each, approximately two weeks after germination. Plants were supplied at regular intervals with $300 \mathrm{ml}$ of water to maintain field capacity. Plant height, leaf chlorophyll, stem diameter, and leaf expansion rates were collected at weekly intervals beginning three weeks after planting. Plants were harvested at respective maturity dates, and fresh and dry weights as well as total yield were taken. Root, leaf and fruit samples were collected to determine phenolic and ascorbic acid content. Vermicompost soil amendment significantly increased plant height of kale and radish compared to the control but had no significant effect on the height of tomato plants. Leaf chlorophyll content was also greater among plants receiving vermicompost amendments except that of kale which declined at highest amendment level. Fresh and dry weight of kale increased with levels of vermicompost amendments with the magnitude of increase being greater between the control plants and those amended with $5 \%$. Tap root yield of radish was highest among plants amended with $15 \%$ vermicompost but yield was similar among amended treatments. Regardless of the treatment, stem diameter was highest in the last few weeks of measurements. Total phenolic content tended to decrease regardless of species with increasing vermicompost levels and vitamin $\mathbf{C}$ increased initially up to $10 \%$ level for kale and declined thereafter, while there was a steady decline in radish. These results show that vermicompost amendments above $10 \%$ may adversely affect plant height and leaf chlorophyll content, while enhancing overall biomass production, and that phenolic and vitamin C responses varied based on vermicompost levels.
\end{abstract}

Keywords: Compost, sustainability, soil, organic matter, chlorophyll.

\section{INTRODUCTION}

Compost from conventional methods and manures are good sources of plant nutrients and organic matter
(Kpomblekou et al., 2002; Toor et al., 2006), improve soil physical and chemical properties and enhance plant 
growth (Boyhan et al., 2010, Russo, 2010). Vermicompost, a rich nutrient rich humus material converted from organic substrates by the activity of earthworms (Eisenia fetida; red wigglers) and microorganisms that has gained renewed interest as a soil amendment. Research has shown that parsley (Petroselinum crispum), tomato (Solanum lycopersicum $\mathrm{L})$, bell pepper (Capsicum annum), lettuce (Lactuca sativa), mustard (Brassica juncea), strawberry (Fragaria spp.), ryegrass (Lolium perenne L), sorghum (Sorghum bicolor), petunias (Petunia spp.), banana (Musa sapientum), and cassava (Manihot esculuntum) have all responded positively to application of both vermicompost and its leachate (tea) (Xu and Mou et al., 2016).

Both vermicompost and its leachate (tea) are nutrientrich and may enhance plant growth singly or in combination with NPK fertilizer (Tekulu, 2019). For example, Chinsamy et al. (2014) reported that the leachate is rich in proteins, vitamins, $\mathrm{N}, \mathrm{P}, \mathrm{K}, \mathrm{Ca}$ and $\mathrm{Mg}$, and helps to maintain soil $\mathrm{pH}$, and when applied as a soil amendment in tomato, increases stem diameter, leaf area, shoot/root fresh and dry weight, chlorophyll, sugars and proline especially under water and temperature stress conditions. Similarly, Pant et al. (2012) showed that the leachate significantly increased plant biomass, plant height, leaf area, root length, and surface area compared to the control in pak choi (Brassica campestris). Chinsamy et al. (2014) treated 1-month old tomato (Solanum lycopersicum $\mathrm{L}$ ) seedlings with and without vermicompost leachate to assess growth responses under low, optimum, and high temperatures of $10,15,20,25$ and $30^{\circ} \mathrm{C}$ and Hoagland's nutrient solution application regimes of 15,30 , and $45 \mathrm{ml}$. They reported increased stem diameter, leaf area, fresh and dry weight, shoot/root length, chlorophyll, sugars and proline, at $30^{\circ} \mathrm{C}$. They concluded that vermicompost leachate can be a suitable soil amendment to improve growth of tomato (Solanum lycopersicum L) plants under temperature and water stress conditions. Shoot and root growth increased significantly in tomato (Solanum lycopersicum L) and lettuce (Lactuca sativa) seedlings with vermicompost tea concentrations of 1 and $5 \%$. (Arancon et al; 2012).

Buckerfield et al. (1999) evaluated the response of pea (Pisum sativum), lettuce (Lactuca sativa), wheat (Triticum aestivum L), cabbage (Brassica oleracea), tomato (Solanum lycopersicum L), and radish (Raphanus sativus) to various combinations of vermicompost amendments ranging from 0 to $100 \%$. Plants responded positively to a $5 \%$ substitution of a 50:50 mixture of pig-cattle-manurevermicompost mixed with a commercial plant growth medium. Similar responses with radish (Raphanus sativus) were observed with 0 to $100 \%$ of vermicompost and sand. However, germination decreased with increasing vermicompost concentrations although the weight of tap roots increased with increasing vermicompost concentrations.

Atiyeh et al. (2000b) reported that vermicompost amendment had the potential for improving growth of raspberry (Rubus occidentalis) when added to media or soil. In this study, the medium was amended with $10-20 \%$ pig manure and food waste based vermicompost. Shoot dry weights were similar to those receiving NPK and greater than those of the controls. Similarly, in a greenhouse study, Xu and Mou (2016) applied vermicompost amendments of 0,5 and $10 \%$ and a liquid drench extract at $0,14,21$ and 28 days after transplanting. Plants receiving the $10 \%$ rate, had higher leaf number, area, plant fresh and dry weight, shoot and root fresh and dry weight, increased water use efficiency, reduced phenolics and flavonoid content. Vermicompost was also reported to increase chlorophyll content in the leaves of marigold (Tagetes erecta; Atiyeh et al., 2000a), mustard (Brassica juncea; Srivastava et al., 2011) and spinach (Spinacia oleracea), especially with the 'tea" applied as a drench (Xu and Mou., 2016) In addition they further indicated that photochemical efficiency also increased in the first three pairs of leaves as well as photosystem II in mature leaves.

While the response of the above-mentioned crops have been documented, there is limited information on biomass response of radish or kale, and even less information on the impact of vermicompost on phenolic and nutrient content of vegetable crops. The objectives of the study was to assess the impact of vermicompost doses of $0,5,10$, and $15 \%(\mathrm{v} / \mathrm{v})$ on yield, total phenolic and vitamin C content of kale (Brasica oleraceae Acephala group), radish (Raphanus sativus) and tomato (Lycopersicum esculentum $\mathrm{L}$ ).

\section{MATERIALS AND METHODS}

\section{Soil collection and reparation}

Soil was collected from an organic plot at George Washington Carver Agricultural Experiment Station in Tuskegee, AL located at latitude $30^{\circ} 27^{\prime} \mathrm{N}$ and $85^{\circ} 42^{\prime} \mathrm{W}$ with an elevation of $470.34 \mathrm{~m}$ above sea level and air dried in a greenhouse for one week. After air drying triplicate subsample was taken to determine the air-dry moisture fraction. The moisture fraction was used to determine the equivalent amount of oven- dried soil to place in each pot. Soil samples (five samples composited) were analyzed by the Plant and Soil Testing Laboratory at Auburn University Alabama, USA(located $32^{\circ} 35^{\prime} 36.0852^{\prime} \mathrm{N}$ and $\left.85^{\circ} 29^{\prime} 42.5868^{\prime} \mathrm{W}\right)$ for $\mathrm{pH}(6.1)$, medium levels $\mathrm{P}, \mathrm{K}$ and $\mathrm{Ca}$ and high levels of $\mathrm{Mg}$, corresponding to 31, 96, 466 , and $178 \mathrm{~kg} \mathrm{ha}^{-1}$, respectively. Based on this analysis, the Recommendation fertilizer rate was NPK at $134-146-112 \mathrm{~kg} \mathrm{ha}^{-1}$.

*Corresponding author. E-mail: dmortley@tuskegee.edu, Fax: 001-334-727-8404

Author(s) agree that this article remain permanently open access under the terms of the Creative Commons Attribution License 4.0 International License 
Table 1. Carbon and elemental concentration of vermicompost used in the study.

\begin{tabular}{lc}
\hline Chemical Constituent & Quantity \\
\hline Carbon (\%) & 39.20 \\
$\mathrm{~N}\left(\mathrm{mg} \mathrm{kg}^{-1}\right)$ & 15,100 \\
$\mathrm{P}\left(\mathrm{mg} \mathrm{kg}^{-1}\right)$ & 1,900 \\
$\mathrm{~K}\left(\mathrm{mg} \mathrm{kg}^{-1}\right)$ & 6,600 \\
$\mathrm{Ca}\left(\mathrm{mg} \mathrm{kg}^{-1}\right)$ & 35,100 \\
$\mathrm{Mg}\left(\mathrm{mg} \mathrm{kg}^{-1}\right)$ & 11,900 \\
$\mathrm{~B}\left(\mathrm{mg} \mathrm{kg}^{-1}\right)$ & 14 \\
$\mathrm{Cu}\left(\mathrm{mg} \mathrm{kg}^{-11}\right)$ & 27 \\
$\mathrm{Fe}\left(\mathrm{mg} \mathrm{kg}^{-1}\right)$ & 1686 \\
$\mathrm{Mn}\left(\mathrm{mg} \mathrm{kg}^{-1}\right)$ & 81.5 \\
$\mathrm{Na}\left(\mathrm{mg} \mathrm{kg}^{-1}\right)$ & 2435 \\
$\mathrm{Zn}\left(\mathrm{mg} \mathrm{kg}^{-1}\right)$ & 225 \\
\hline
\end{tabular}

Fertilizer was applied to the bulk soil before being placed into $19 \mathrm{~cm}$ diameter greenhouse pots.

\section{Determining gravimetric moisture fraction}

The amount of oven dry soil per pot was determined following the methods of Gardener, (1986). A one-liter graduated cylinder was filled with air dried soil, covered with a paper towel and $100 \mathrm{ml}$ of deionized water were added and allowed to stand for 24 hours. After 24 hours a sample was collected at a depth of $5 \mathrm{~cm}$ above the wetting point, weighed and dried in a Precision Thelco Incubation Oven (Thelco Electron Corp Maple Lake, Minnesota, USA) at $100^{\circ} \mathrm{C}$ to a constant weight and dry weight recorded. Gravimetric moisture fraction was calculated as follows:

All the air-dried soil to be used in the pots was bulked and 3 subsamples of $25 \mathrm{~g}$ each were dried at $100^{\circ} \mathrm{C}$ to a constant weight. Two empty pots were weighed, and filled with air dried soil to within 2- $4 \mathrm{~cm}$ of the top and the equivalent amount of oven dried soil was determined.

\section{Preparing vermicompost}

Worms and a Worm Factory $360(46 \times 38 \times 46 \mathrm{cn})$ were obtained from GA Wiggler Worm Farm (Covington, Georgia, USA $\left.33^{\circ} 37^{\prime} 06.7^{\prime \prime} \mathrm{N} 83^{\circ} 50^{\prime} 37.3^{\prime \prime} \mathrm{W}\right)$. Organic materials for worm feed were weighed and added to the trays in the worm factory and the worms released into the trays. The worms were fed weekly with a 1:1 ratio of food material (vegetables) and shredded paper. The trays watered with $500 \mathrm{ml}$ of water to maintain a moisture content of 60 $75 \%$ water holding capacity and tray temperatures averaged $25^{\circ} \mathrm{C}$ with an ambient of $26^{\circ} \mathrm{C}$. Vermicompost was harvested after 60 days and samples were analyzed by the Plant and Soil Testing Laboratory at Auburn University, Alabama USA (located $32^{\circ} 35^{\prime}$ $36.0852^{\prime} \mathrm{N}$ and $85^{\circ} 29^{\prime} 42.5868^{\prime} \mathrm{W}$ ) for total carbon, $\mathrm{N}, \mathrm{P}, \mathrm{K} \mathrm{Ca}$, $\mathrm{Mg}, \mathrm{B}, \mathrm{Cu}, \mathrm{Fe}, \mathrm{Mn}, \mathrm{Na}$, and $\mathrm{Zn}$ (Table 1).

\section{Treatments and planting}

The treatments were vermicompost levels of $0,5,10$ and $15 \%$ and each pot had a final volume of $2.52 \mathrm{~kg}$ including the vermicompost treatments. Each pot was direct-seed with $3-5$ seeds and thinned to one per pot for tomato (Solanum lycopersicum $L$ ) variety Mountain Spring and kale (Brassica oleracea Acephala group), variety Red Russian, but not for radish (Raphanus sativus), variety Early Scarlet Globe $\sim 3$ weeks after planting. Plants were watered at regular intervals throughout with $300 \mathrm{ml}$ of doubly deionized water to maintain field capacity. Temperature in the greenhouse averaged about $24^{\circ} \mathrm{C}$.

\section{Determination of vitamin $\mathbf{C}$ and total phenolic and lycopene conteent}

Leaf samples of kale and radish and fruit samples of tomato were analyzed for vitamin $\mathrm{C}$, by titration according to the methods of the US Pharmacopoeia (USP 1980). One gram of sample was added to $50 \mathrm{ml}$ of deionized water, filtered and brought to a final volume of $100 \mathrm{ml}$ with deionized water. A $20 \mathrm{ml}$ aliquot was pipetted into a $250 \mathrm{ml}$ conical flask and $150 \mathrm{ml}$ of deionized water were added along with $1 \mathrm{ml}$ of a starch solution $(0.50 \mathrm{~g}$ of soluble starch in 50 $\mathrm{ml}$ of $100^{\circ} \mathrm{C}$ deionized water. Samples were titrated with $0.005 \mathrm{~mol}$ $\mathrm{L}-1^{-1}$ of iodine solution to blue at endpoint. Total phenolics were determined using gallic acid according to the method of Slinkard and Singleton (1977). One gram samples were placed in opaque bottles and $25 \mathrm{ml}$ of $95 \%$ methanol were added, agitated for $30 \mathrm{~min}$ after which another $25 \mathrm{ml}$ of methanol were added to each sample. Samples were filtered, brought up to $50 \mathrm{ml}$ with $95 \%$ methanol and thoroughly mixed. Approximately $20 \mu \mathrm{l}$ of each sample were pipetted into cuvettes, followed by $1.58 \mathrm{ml}$ of deionized water, 100 $\mu \mathrm{l}$ of folin coulteau and $300 \mu \mathrm{l}$ of $\mathrm{NaCO}_{3}$ and allowed to sit in the dark for two hr. Absorbance was measured at a wavelength of 765nm using a Shimadzu UV-2401 PC UV-VIS Spectrophotometer (New District Suzhou, China). and samples were read using a Shimadzu UV-2401 PC UV-VIS Spectrophotometer (New District Suzhou, China) at a wavelength of $765 \mathrm{~nm}$. Lycopene content was determined on tomato fruits only following the method of Toor et al. (2006). Fruit samples (1-gram)g) were extracted with $25 \mathrm{ml}$ of a hexane: ethanol: acetone mixture, on a rotary shaker for $30 \mathrm{~min}$ after which $10 \mathrm{ml}$ of distilled water were added. Samples were placed in the shaker for an additional 2 min and kept at room temperature for $5 \mathrm{~min}$ to allow for phase separation. Absorbance was measured at $503 \mathrm{~nm}$ using a spectrophotometer (Shimadzu UV-2401 PC UV-VIS) and the lycopene content estimated.

\section{Data collection}

Plants were grown following standard cultural practices, and data collected included chlorophyll content using a CCM200 plus Chlorophyll Content Meter (Apogee Instruments, Logan Utah), plant height, stem diameter, and leaf expansion rates at weekly intervals beginning three weeks after planting. Light intensity was measured weekly using a Model QMSW-SS quantum meter (Apogee Instruments, Logan Utah). Plants were harvested for yield of economic importance (leaves, tap root, fruits) at 62, 76 and 96 days after planting for radish (Raphanus sativus), kale (Brassica oleracea Acephala group), and tomato (Solanum lycopersicum $\mathrm{L}$ ). Total leaf area was determined from leaf samples collected at harvest, using LICOR-1800 leaf area meter (LI-COR, Lincoln, Nebraska). Fresh weights of foliage, fruits, and root, as well as root length and diameter were taken, and subsamples collected for nutritional analysis. Samples were dried in ovens at $65^{\circ} \mathrm{C}$ for 72 hours and the dry weights recorded.

\section{Experimental design and statistical analysis}

The experiment was conducted as a completely randomized design with three crops radish (Raphanus sativus), kale (Brassica oleracea 
Table 2. Effect of vermicompost on foliage fresh and dry weight and dry matter (\%) of kale ${ }^{z}$.

\begin{tabular}{cccc}
\hline \multirow{2}{*}{ Vermicompost $(\% \mathbf{v} / \mathbf{v})$} & \multicolumn{2}{c}{ Foliage weight $\left(\mathbf{g}\right.$ plant $\left.^{-1}\right)$} & \multirow{2}{*}{ Dry matter $(\%)$} \\
\cline { 2 - 3 } & Fresh & Dry & $16.6^{\mathrm{a}}$ \\
\hline 0 & $2.5^{\mathrm{b}}$ & $0.3^{\mathrm{b}}$ & $12.2^{\mathrm{b}}$ \\
5 & $42.8^{\mathrm{a}}$ & $3.1^{\mathrm{a}}$ & $12.7^{\mathrm{b}}$ \\
15 & $56.9^{\mathrm{a}}$ & $3.9^{\mathrm{a}}$ & $12.2^{\mathrm{b}}$ \\
\hline
\end{tabular}

${ }^{z}$ Means within a column with the same letter are not significantly different (Tukey's 0.05 ). Data in table were portioned per crop species.

Table 3. Effect of vermicompost on foliage and storage root fresh and dry weight and percent root dry matter of radish ${ }^{z}$.

\begin{tabular}{c|cc|cc|c}
\hline \multirow{2}{*}{ Vermicompost (\% v/v) } & \multicolumn{2}{|c|}{ Foliage weight $\left(\mathbf{g}\right.$ plant $\left.\mathbf{~}^{-1}\right)$} & \multicolumn{2}{|c|}{ Root weight (\%) } & \multirow{2}{*}{ Dry matter (\%) } \\
\cline { 2 - 5 } & Fresh & Dry & Fresh & Dry & \\
\hline 0 & $5.3^{\mathrm{c}}$ & $0.50^{\mathrm{c}}$ & $12.0^{\mathrm{b}}$ & $0.5^{\mathrm{b}}$ & $4.2^{\mathrm{b}}$ \\
5 & $39.0^{\mathrm{b}}$ & $2.3^{\mathrm{b}}$ & $55.7^{\mathrm{a}}$ & $4.4^{\mathrm{a}}$ & $7.9^{\mathrm{a}}$ \\
10 & $52.0^{\mathrm{ab}}$ & $3.0^{\mathrm{ab}}$ & $48.5^{\mathrm{ab}}$ & $3.5^{\mathrm{a}}$ & $7.2^{\mathrm{a}}$ \\
15 & $53.0^{\mathrm{a}}$ & $3.2^{\mathrm{a}}$ & $73.2^{\mathrm{a}}$ & $4.8^{\mathrm{a}}$ & $6.6^{\mathrm{a}}$ \\
\hline
\end{tabular}

${ }^{z}$ Means within a column with the same letter are not significantly different (Tukey's 0.05$)$. Dry matter (\%) was calculated based on root values only. Data in table were portioned per crop species.

Acephala group), and tomato (Solanum lycopersicum $L$ ), four vermicompost treatments of $0,5,10$, and $15 \%(\mathrm{v} / \mathrm{v})$ and four replications.

All data were combined by replication and crop species and analyzed using one-way ANOVA (SAS, 2009) Inst. Inc. Cary, North Carolina). Differences between means were determined by student's $t$ test at 0.05 level of probability.

\section{RESULTS}

Vermicompost increased foliage fresh and dry weight of kale, but was only significant with respect to the control plants (Table 2). Although foliage fresh and dry biomass were enhanced by each $5 \%$ increment of vermicompost, the difference among the treatments were not significant. Foliage fresh weight of radish also increased with increased vermicompost especially between 5 and $10 \%$ (Table 3). While dry weight increased likewise, the magnitude was much smaller. The fresh and dry weights of radish roots also increased (except at 10\% level) compared to that of the control plants but were similar among treatments. The percent dry matter of radish roots increased significantly as the percentage of vermicompost increased in the growth medium.

The fresh and dry weights of tomato foliage (Table 4) increased with vermicompost amendment with plants receiving the 10 and $15 \%$ levels being highest. While there were no differences among plants receiving 10 and $15 \%$, there was an approximate of $42 \%$ greater fresh weight among plants receiving $10 \%$ compared to $5 \%$ levels. Total fruit number and weight increased with vermicompost levels. Fruit weight was approximately threefold greater among plants receiving $10 \%$ vermicompost amendments versus plants receiving the $5 \%$ amendment, but this difference was not statistically significant Commensurate with the increase in mean fruit number there was an increase in mean fruit weight at $15 \%$ vermicompost level but did not differ significantly from that at $10 \%$ level.

Vermicompost amendment had no significant impact on stem diameter of either species (Table 5). However, plant height for kale and radish increased with vermicompost amendment up to $10 \%$ but was similar for tomato, regardless of treatment. Total leaf area increased with vermicompost amendment and was significant for kale with respect only to the control. Total leaf area for radish plants receiving the 10 and $15 \%$ treatments was similar and significantly greater than that obtained from control plants. Mean leaf chlorophyll was highest among kale plants receiving $10 \%$, and increased with respect to the control. However, leaf chlorophyll declined between 10 and $15 \%$ levels. In contrast, leaf chlorophyll generally increased with vermicompost levels. There were no differences among the vermicompost treatmerts in leaf chlorophyll.

Nitrogen concentration increased with vermicompost for all three species (Table 6). Elemental leaf $\mathrm{N}$ concentration was lowest for tomatoes. Vermicompost amendments had no significant impact on $\mathrm{P}$ concentration in kale or radish, but it appeared that $\mathrm{P}$ concentration was 
Table 4. Effect of vermicompost on foliage fresh and dry weight and fruit yield of tomato. ${ }^{2}$

\begin{tabular}{ccccc}
\hline \multirow{2}{*}{ Vermicompost $(\% \mathbf{~ v} / \mathbf{v})$} & \multicolumn{2}{c}{ Foliage weight $\left(\mathbf{g}\right.$ plant $\left.{ }^{-1}\right)$} & \multicolumn{2}{c}{ Fruit weight $\left(\mathbf{g}\right.$ plant $\left.^{-1}\right)$} \\
\cline { 2 - 5 } & Fresh & Dry & No. & Fruit wt. \\
\hline 0 & $9.5^{\mathrm{c}}$ & $0.5^{\mathrm{c}}$ & $0.00^{\mathrm{c}}$ & $0.00^{\mathrm{b}}$ \\
5 & $80.8^{\mathrm{b}}$ & $12.6^{\mathrm{b}}$ & $3.25^{\mathrm{b}}$ & $89.3^{\mathrm{ab}}$ \\
10 & $139.8^{\mathrm{a}}$ & $20.4^{\mathrm{a}}$ & $5.50^{\mathrm{a}}$ & $237.6^{\mathrm{a}}$ \\
15 & $146.8^{\mathrm{a}}$ & $23.8^{\mathrm{a}}$ & $5.25^{\mathrm{ab}}$ & $258.4^{\mathrm{a}}$ \\
\hline
\end{tabular}

${ }^{z}$ Means within a column with the same letter are not significantly different (Tukey's 0.05 ). Data in table were portioned per crop species.

Table 5. Effect of vermicompost on stem diameter, plant height, total leaf area and leaf chlorophyll of kale, radish and tomato ${ }^{z}$

\begin{tabular}{|c|c|c|c|c|}
\hline Vermicompost (\%) & Stem $^{2}$ diameter $(\mathrm{mm})$ & Plant height $(\mathrm{cm})$ & Leaf area $\left(\mathrm{cm}^{2}\right)$ & Leaf Chlorophyll $\left(\mu \mathrm{mol} \mathrm{m}^{-2}\right)$ \\
\hline \multicolumn{5}{|c|}{ Kale } \\
\hline 0 & $4.8^{\mathrm{a}}$ & $9.3^{b}$ & $53.7^{b}$ & $87.3^{\mathrm{b}}$ \\
\hline 5 & $9.3^{\mathrm{a}}$ & $22.9^{\mathrm{a}}$ & $560.9^{a}$ & $225.0^{\mathrm{ab}}$ \\
\hline 10 & $9.5^{\mathrm{a}}$ & $21.5^{\mathrm{a}}$ & $868.9^{a}$ & $358.0^{\mathrm{a}}$ \\
\hline 15 & $9.3^{\mathrm{a}}$ & $19.2^{\mathrm{a}}$ & $1060.0^{\mathrm{a}}$ & $208.3^{\mathrm{ab}}$ \\
\hline \multicolumn{5}{|l|}{ Radish } \\
\hline 0 & $4.6^{\mathrm{a}}$ & $7.1^{\mathrm{b}}$ & $194.5^{\mathrm{c}}$ & $51.9^{\mathrm{b}}$ \\
\hline 5 & $8.3^{\mathrm{a}}$ & $13.4^{\mathrm{ab}}$ & $1062.5^{\mathrm{b}}$ & $184.3^{\mathrm{a}}$ \\
\hline 10 & $9.3^{\mathrm{a}}$ & $13.9^{\mathrm{a}}$ & $1324.1^{\mathrm{a}}$ & $164.2^{\mathrm{a}}$ \\
\hline 15 & $7.9^{\mathrm{a}}$ & $11.5^{\mathrm{ab}} \quad 1$ & $1297.9^{\mathrm{ab}}$ & $190.2^{\mathrm{a}}$ \\
\hline \multicolumn{5}{|l|}{ Tomato } \\
\hline 0 & $5.3^{\mathrm{a}}$ & $31.1^{\mathrm{a}}$ & $124.1^{\mathrm{a}}$ & $114.3^{b}$ \\
\hline 5 & $11.1^{\mathrm{a}}$ & $47.4^{\mathrm{a}}$ & $881.8^{\mathrm{a}}$ & $151.8^{b}$ \\
\hline 10 & $11.1^{\mathrm{a}}$ & $50.8^{\mathrm{a}}$ & $1103.9^{\mathrm{a}}$ & $247.8^{\mathrm{a}}$ \\
\hline 15 & $11.1^{\mathrm{a}}$ & $48.0^{\mathrm{a}}$ & $1178.9^{\mathrm{a}}$ & $323.8^{\mathrm{a}}$ \\
\hline
\end{tabular}

${ }^{z}$ Means within a column with the same letter are not significantly different (Tukey's 0.05). Data in table were portioned per crop species.

depressed in tomato plants at $5 \%$ level of amendment. Similarly, K concentration increased with vermicompost amendment among all three species. Calcium levels in kale and tomato was not significantly influenced by vermicompost amendments. Leaf $\mathrm{Mg}$ was similar in kale and significant in radish and and only at $5 \%$ level in tomato. Sodium levels were extremely high in the leaves of all three species which is a general reflection of the source of the materials that were fed to the worms. The same results were generally true for $\mathrm{Fe}$ as well.

Vitamin C content in kale (Figure. 1) was similar among 0,5 and $10 \%$, but declined at $15 \%$ level. In contrast, vitamin C content of radish and tomato declined substantially as the percentage of vermicompost in the growth medium increased. Total phenolics of kale (Figure. 2) were similar at 5 and $10 \%$ but significantly lower at $15 \%$ while that for radish was generally similar. Kale plants grown at $0 \%$ levele were too small to provide enough leaf samples for analysis.

There was a drop in lycopene content among plants exposed to the 5 or $10 \%$ vermicompost amendment presumably related to fruit maturity. Tomato plants grown at $0 \%$ level produced no fruits to provide samples for analysis (Figure 3 ).

\section{DISCUSSION}

Vermicompost, especially at $10 \%$ increased foliage fresh and dry biomass of kale, foliage fresh, dry biomass, and root yield of radish and foliage fresh and dry biomass and fruit yield of tomato. Vermicompost amendments also increased stem diameter, plant height, total leaf area and leaf chlorophyll, for all three species\, particularly at $10 \%$ level of amendment. Lean $\mathrm{N}, \mathrm{P}, \mathrm{K}, \mathrm{Ca}$, and $\mathrm{Na}$ all increased in response to vermicompost amendments, while $\mathrm{Mg}$ and $\mathrm{Fe}$ (kale only) declined. The levels of nutrients in the leaves of all three species equaled or exceeded the standard values associated with optimum production (Mills and Jones, 1996). This study shows that 
Table 6. Elemental leaf concentration of kale, radish and tomato in response to vermicompost amendments.

\begin{tabular}{|c|c|c|c|c|c|c|c|}
\hline \multirow{2}{*}{ Vermicompost $(\% \mathbf{v} / \mathbf{v})$} & $\mathbf{N}$ & $\mathbf{P}$ & $\mathrm{K}$ & $\mathrm{Ca}$ & $\mathbf{M g}$ & $\mathrm{Na}$ & $\mathrm{Fe}$ \\
\hline & \multicolumn{5}{|c|}{$\left(\mathrm{g} \mathrm{kg}^{-1}\right)$} & \multicolumn{2}{|c|}{$\left(\mu \mathrm{g} \mathrm{g}^{-1}\right)$} \\
\hline \multicolumn{8}{|l|}{ Kale } \\
\hline 0 & -- & $4.3^{\mathrm{a}}$ & $28.3^{\mathrm{c}}$ & $1.16^{\mathrm{a}}$ & $9.5^{\mathrm{a}}$ & $960.5^{c}$ & $120.5^{a}$ \\
\hline 5 & $43.1^{\mathrm{b}}$ & $4.9^{\mathrm{a}}$ & $41.9^{b c}$ & $1.44^{\mathrm{a}}$ & $7.5^{\mathrm{a}}$ & $2572.0^{b}$ & $120.5^{\mathrm{a}}$ \\
\hline 10 & $50.8^{a b}$ & $4.4^{\mathrm{a}}$ & $4.77^{\mathrm{ab}}$ & $13.9^{\mathrm{a}}$ & $6.7^{\mathrm{a}}$ & $3486.5^{\mathrm{a}}$ & $95.7^{\mathrm{a}}$ \\
\hline 15 & $59.8^{\mathrm{a}}$ & $5.5^{\mathrm{a}}$ & $5.59^{\mathrm{a}}$ & $14.8^{\mathrm{a}}$ & $7.1^{\mathrm{a}}$ & $3601.0^{\mathrm{a}}$ & $117.0^{\circ}$ \\
\hline \multicolumn{8}{|l|}{ Radish } \\
\hline 0 & $22.6^{\mathrm{c}}$ & $3.6^{\mathrm{a}}$ & $3.56^{\mathrm{b}}$ & $20.6^{c}$ & $14.1^{\mathrm{a}}$ & $869.0^{\mathrm{b}}$ & $359.5^{\mathrm{a}}$ \\
\hline 5 & $46.7^{b}$ & $3.2^{\mathrm{a}}$ & $4.51^{\mathrm{ab}}$ & $22.1^{\mathrm{bc}}$ & $9.9^{b}$ & $5193.8^{a}$ & $314.7^{\mathrm{a}}$ \\
\hline 10 & $57.0^{\mathrm{a}}$ & $3.4^{\mathrm{a}}$ & $4.57^{\mathrm{a}}$ & $27.9^{\mathrm{a}}$ & $9.8^{\mathrm{b}}$ & $5496.3^{\mathrm{a}}$ & $245.2^{\mathrm{a}}$ \\
\hline 15 & $57.4^{\mathrm{a}}$ & $3.3^{\mathrm{a}}$ & $4.70^{\mathrm{a}}$ & $27.2^{\mathrm{ab}}$ & $9.6^{\mathrm{b}}$ & $5735.5^{\mathrm{a}}$ & $259.0^{\circ}$ \\
\hline \multicolumn{8}{|l|}{ Tomato } \\
\hline 0 & $13.2^{b}$ & $2.4^{\mathrm{a}}$ & $1.90^{\mathrm{b}}$ & $14.3^{\mathrm{a}}$ & $12.4^{\mathrm{a}}$ & $858.5^{\mathrm{ab}}$ & $89.0^{\mathrm{a}}$ \\
\hline 5 & $16.6^{\mathrm{b}}$ & $1.4^{\mathrm{b}}$ & $2.06^{\mathrm{b}}$ & $12.8^{\mathrm{a}}$ & $7.1^{b}$ & $731.0^{\mathrm{b}}$ & $81.8^{a}$ \\
\hline 10 & $25.8^{\mathrm{a}}$ & $2.1^{\mathrm{ab}}$ & $2.59^{\mathrm{ab}}$ & $14.3^{\mathrm{a}}$ & $8.7^{\mathrm{ab}}$ & $1056.3^{\mathrm{a}}$ & $87.8^{\mathrm{a}}$ \\
\hline 15 & $30.4^{\mathrm{a}}$ & $3.5^{\mathrm{a}}$ & $3.01^{\mathrm{a}}$ & $12.9^{\mathrm{a}}$ & $8.4^{\mathrm{ab}}$ & $1173.5^{\mathrm{a}}$ & $91.3^{\mathrm{a}}$ \\
\hline
\end{tabular}

${ }^{z}$ Means within a column with the same letter are not significantly different (Tukey's 0.05 ). Data in table were portioned per crop species. --Not enough samples for analysis.

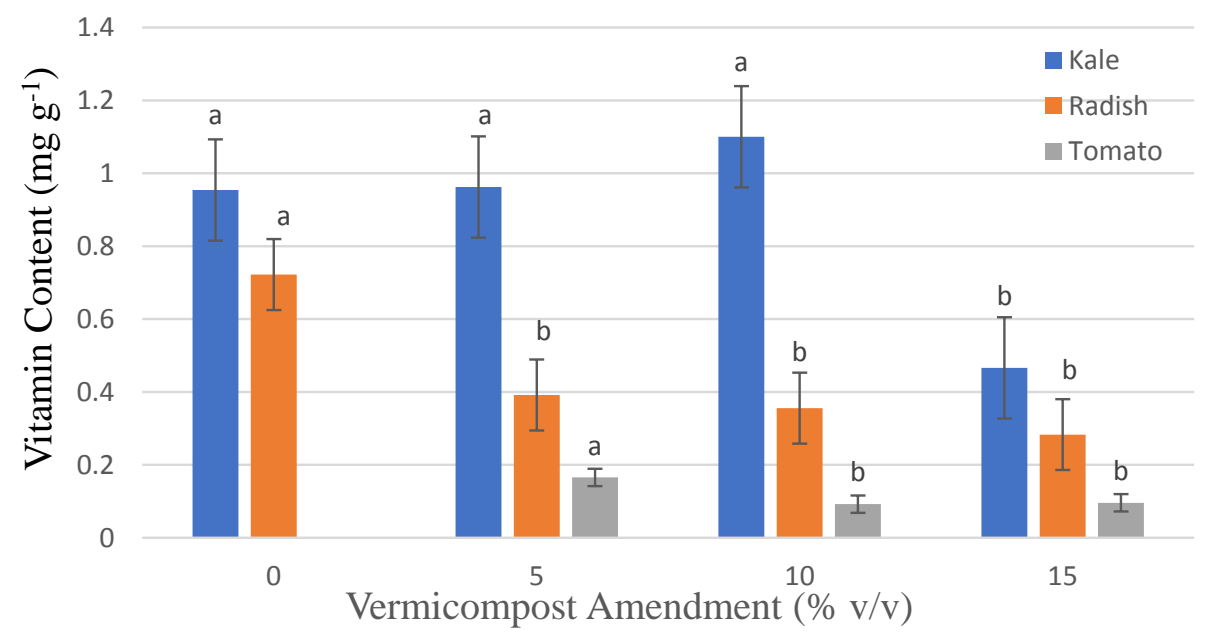

Figure 1. Effect of vermicompost amendments on total vitamin $\mathrm{C}$ content of kale, radish and tomato. Same letters on bars are not significantly different (Tukey's 0.05).

chlorophyll content increased with vermicompost levels in all three crops. Vermicompost was also reported to increase chlorophyll content in marigold (Atiyeh et al., 2000a) and mustard leaves (Srivastava et al., 2011). This supports the results of a previous study ( $\mathrm{Xu}$ and Mou, 2016) which reported chlorophyll content of spinach increased under all vermicompost treatments, especially the drench treatment.

It is worthy of note that these vegetable crops responded to vermicompost amendments especially at
$10 \%$ rate though three species were used. This appears to be consistent across species as similar results have been reported for other crops whether a leachate, tea or compost was used. These include, pak choi (Pant et al., 2012), tomato seedlings (Chinsamy et al., 2014) and spinach (Xu and Mou, 2016). The researchers asttributed these positive crop responses to the favorable chemical properties of vermicompost. For example, the vermicompost used in this study was produced in-house and had a high content of carbon, macro- and 


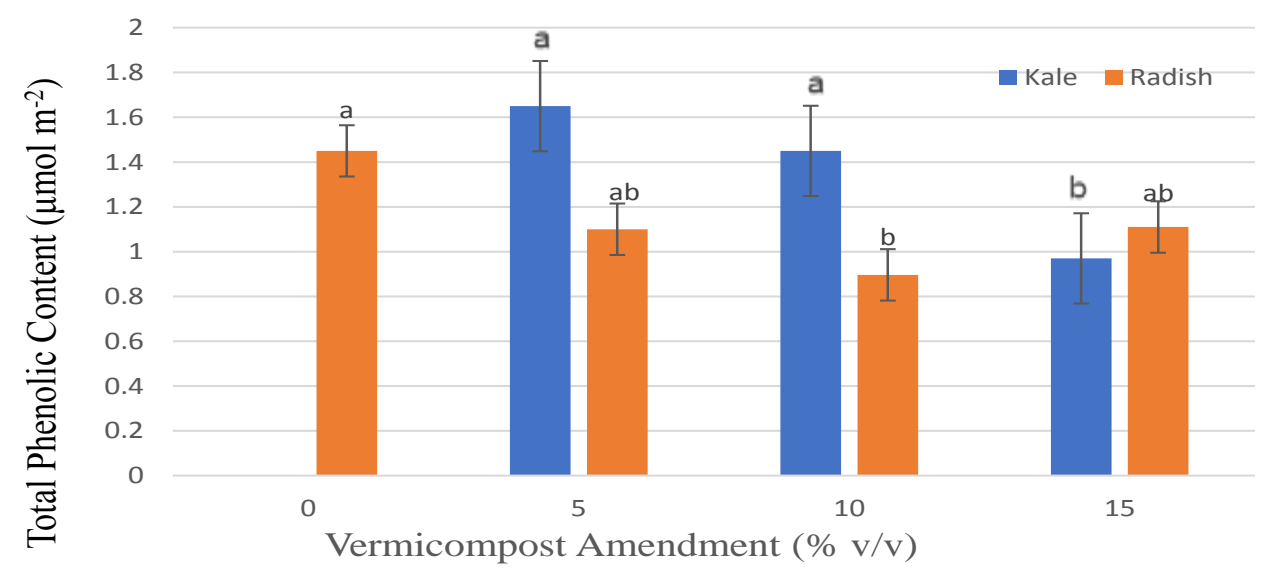

Figure 2. Effect of vermicompost amendments on total phenolic content of kale and radish. Note, not enough sample for kale control plamts. Same letters on bars are not significantly different (Tukey's 0.05).

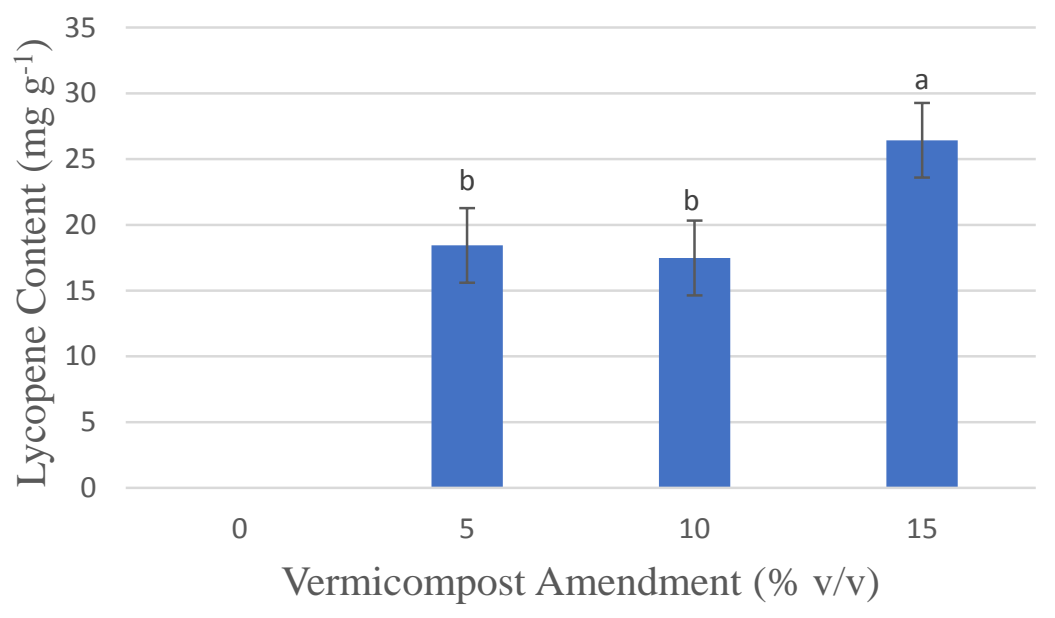

Figure 3. Effect of vermicompost amendments on total lycopene content of tomato fruits. Note, not enough sample for control plamts. Same letters on bars are not significantly different (Tukey's 0.05 ).

micronutruients which may have contributed to increasing the soil fertility ( $\mathrm{Xu}$ and Mou, 2016), thus having a positive impact on biomass production. Generally, the magnitude of the increase in biomass was greater between 5 and $10 \%$ as well as negligible between 10 and $15 \%$ vermicompost amendment.

Vitamin $\mathrm{C}$ varied depending on the species, increasing up to $10 \%$ rate for kale but decreased significantly for radish and tomato. Vitamin $\mathrm{C}$ is synthesized via $\mathrm{L}$ galactose catalyzed by L-galactose dehydrogenase (Wheeler et al, 1998). Thus the increase in vitamin C content in kale could be due in part to a decrease in protein production with a commensurate increase in carbohydrate production, and the converse would be true for radish and tomatoes (Muso and Ogbadoyi, 2012; Staley et al., 2013). Total phenolic content decreased overall with increasing vermicompost levels. Similar results were reported for pak choi (Pant et al., 2012) and spinach (Xu and Mou, 2016). Xu amd Mou (2016) suggested that phenolics are a class of secondary metabolites that function as antioxidants, and important group of which is flavonoids.

The lycopene content in tomato fruits increased with the percentage of vermicompost amendments and was highest at $15 \%$ rate. Lycopene content in fruits and vegetables is influenced by many factors, including the stage of ripening, seasonal production and nutrients supplied, light quality and quantity, air temperature and 
levels of salinity in nutrient solutions (Perkins-Veazie et al., 2007; Alba et al., 2000; De Pascale, 2001). In this study, tomatoes were planted and cultivated in the greenhouse and harvested in the fall and winter. Due to the seasonal variations of light and temperature, the tomato fruits took much longer to ripen and fruits were harvested at pink and light red stages and stored in the cooler for later use. Perkins-Veazie et al. (2007) and Alba et al. (2000) have reported that tomatoes exposed to high levels of light during field ripening, may have increased the phytochrome activity in the exocarp, thereby increasing the lycopene content. In contrast, Toor et al. (2006) reported positive correlation between lycopene content and fruit color. They found that light-red fruits and red fruits had higher lycopene contents similar to, or exceeding that obtained from fruits at soft red stage. In this study, increasing vermicompost amendments appeared to have had a positive effect on lycopene levels as content was highest at $15 \%$ rate.. In addition, Toor et al. (2006) reported that lycopene levels were reduced by the application of organic amendments.

\section{CONCLUSION}

These results show that vermicompost amendments above $10 \%$ may adversely affect plant height and leaf chlorophyll content, while enhancing overall biomass production, and that phenolic and vitamin $C$ responses varied based on vermicompost levels.

\section{CONFLICT OF INTERESTS}

The authors have not declared any conflict of interest.

\section{ACKNOWLEDGEMENT}

The authors appreciates the contribution of the George Washington Carver Agricultural Experiment Station, Tuskegee University. They are grateful for the funds given by USDA/NIFA Evans-Allen Grant No. ALX-FV.

\section{REFERENCES}

Alba R, Cordonnier-Pratt MM, Pratt LH (2000). Fruit-localized phytochromes regulate lycopene accumulation independently of ethylene production in tomato. Plant Physiology 123(1):363-370.

Arancon NQ, Pant A, Radovich T, Hue N, Potter JK, Converse CE (2012). Seed germination and seedling growth of tomato and lettuce as affected by vermicompost water extracts (Teas). HortScience 47(12):1722-1728.

Atiyeh RM, Edwards C, Subler S, Metzger J (2000a). Earthwormprocessed organic wastes as components of horticultural potting media for growing marigold and vegetable seedlings. Compost Science and Utilization 8(3):215-223.

Atiyeh RM, Subler S, Edwards CA, Bachman G, Metzger JD, Shuster W (2000b). Effects of vermicomposts and composts on plant growth in horticultural container media and soil. Pedobiologia 44(5):579-590.
Boyhan G, Hicks RJ, Torrance RL, Riner CM, Hill CR. (2010). Evaluation of poultry litter and organic fertilizer rate and source for production of organic short-day onions. HortTechnology 20(2):304307.

Buckerfield JC, Flavel T, Lee KE, Webster KA (1999). Vermicomposts in solid and liquid form as plant-growth promoter. Pedobiolgia 43(6):753-759.

Chinsamy M, Kulkarni M, Staden J (2014). Vermicompost leachate reduces temperature and water stress effects in tomato seedlings. HortScience 49(9):1183-1187.

De Psacale S, Maggio A, Fogliano V, Ambrosino P, Ritieni A (2001). Irrigation with saline water improves carotenoids content and antioxidant activity of tomato. Journal of Horticultural Science and Biotechnology 76(4):447-453.

Gardener WH (1986). Water content. Chap 21 in Khute, A. ed. Methods of soil analysis. Soil Science Society of America, Madison WI.

Kpomblekou-AK, Ankumah RO, Ajwa HA (2002). Trace and non-trace element contents of broiler litter. Communications in Soil Science and Plant Analysis 33(11-12):1799-1811.

Mills HA, Jones JB (1996). Plant analysis handbook II. MicroMacro Pub. Inc. Athens, GA.

Muso A, Ogbadoyi EO (2012). Effect of nitrogen fertilizer on the levels of some nutrients, antinutrients and toxic substances in hibiscus sabdariffa. Asian Journal of Crop Science 4(3):103-112.

Pant AP, Radovich TJK, Ngyuyen H, Miyasaka SC (2012). Pak Choi (Brassica rapa, Chinensis Group) yield, phytonutrient content, and soil biological properties as affected by vermicompost-to-water ratio used for extraction. HortScience 47(3):1722-1728.

Perkins-Veazie P, Roberts W, Collins JK (2007). Lycopene content among organicallyproduced tomatoes. Journal of Vegetable Science 12(4):93-106.

Russo V (2010). Frequency of manure application in organic versus annual application of synthetic fertilizer in conventional vegetable production. Horticulture Science 45(11):1673-1680.

SAS Institute (2009). SAS user's guideStatistics. SAS Inst., Cary, NC.

Srivastava PK, Singh PC, Gupta M, Sinha A, Vaish A, Shukla A, Singh $\mathrm{N}$, Tewari SK (2011). Influence of earthworm culture on fertilization potential and biological activities of vermicomposts prepared from different plant wastes. Journal of Plant Nutrition and Soil Science 174(3):420-429.

Slinkard K, Singleton VL (1977). Total phenolanalysis: Automation and comparison with manual methods. American journal of enology and viticulture 28(1):49-55.

Staley L, Mortley DG, Bonsi CK, Bovell-Benjamin A, Gichuhi P (2013). Hydrolyzed organic fish fertilizer and poultry litter influence total phenolics and antioxidants content but not yield of amaranth, celosia, gboma and long bean HortScience, 48(6):768-772.

Tekulu K, Tadele T, Berhe T, Gebrehiwot W, Kahsu G, Mebrahtom S, Aregawi G, Tasew G (2019). Effect of vermicompost and blended fertilizers rates on yield and yield components of Tef (Eragrostis tef (Zucc.) Trotter). Journal of Soil Science and Environmental Management 10(6):130-141.

Toor RK, Savage GP, Heeb A (2006). Influence of different types of fertilizers on the major antioxidant components of tomatoes Journal of Food Composition and Analysis 19(1):20-27.

United States Pharmacopoeia (USP) (1980). United States Pharmacopoeia $20^{\text {th }}$ Revision, Mack Co., Easton PA, P 55. https://www.usp.org

Wheeler GL, Jones MA, Smirnoff N (1998). The biosynthetic pathway of vitamin $C$ in higher plants. Nature 343(6683):365-369.

Xu C, Moun B (2016). Vermicompost affects soil properties and spinach growth, physiology, and nutritional value. HortScience 51(7):847-855. 